\title{
ПІДСТАВИ НЕДІЙСНОСТІ ПРАВОЧИНУ
}

\author{
КОТУХА Олександр - професор кафедри господарського права та \\ процесу, декан юридичного факультету Львівського торговельно-економічного \\ університету \\ ЧАБАН Олена - доцент кафедри цивільного права та процесу Львівського \\ торговельно-економічного університету \\ ЛОЗИНСЬКА Тетияна - студентка освітнього ступеня "магістр" другого \\ року навчання юридичного факультету Львівського торговельно-економічного \\ факультету \\ УДК 347.133.2 \\ DOI 10.32782/NP.2020.4.21
}

У статті аналізуються підстави недійсності правочину. Вказуються, що загальні підстави недійсності правочину визначені ч. $1 \mathrm{~cm} .215$ Цивільного кодексу України. Ця норма є відсильною, тому необхідно застосовувати положення ст. 203 Цивільного кодексу України.

Характеризуються загальні вимоги чинності правочину, при недотриманні яких сторонами правочину чи однією стороною, вони $\epsilon$ підставами недійсності правочину.

У статті визначені поняття "зміст правочину”, “інтереси держави i суспільства”, “моральні засади суспільства”. Однією з підстав недійсності правочину є недодержання вимоги про відповідність змісту правочину Цивільному кодексу України, іншим законам, інтересам держави і суспільства, моральним засадам суспільства.

Окреслений необхідний обсяг дієздатності фбізичної особи для вчинення нею дійсного правочину. Визначені види дієздатності ббізичноі особи, вказано, які правочини може вчиняти фізична особа при наявності певного виду дiєздатності.

Проаналізовані поняття “внутрішня воля” та “вільне волевиявлення”. Невідповідність волевиявлення учасника правочину його внутрішній волі є підставою недійсності правочину.

Недодержання вимоги закону щодо письмової борми правочину, встановленої законом, $\epsilon$ підставою недійсності правочину тільки у випадку, коли че прямо передбачено законом. Таких випадків у законі є декілька, цее, в основному, вказується щодо договорів.

Однією з підстав недійсності правочину $\epsilon$ вчинення удаваного або біктивного правочинів. Пояснюється правильне застосовування норм щодо удаваного та біктивного правочинів. Загальним правилом є те, що правочин має бути спрямований на реальне настання правових наслідків, що обумовлені ним.

Останнъою загальною підставою недійсності правочину є порушення батьками (усиновлювачами) прав та інтересів їхніх малолітніх, неповнолітніх чи непрацездатних дітей при вчиненні правочинів. Законом передбачена вимога одержання дозволу органу опіки та піклування при укладенні договорів батьками (усиновлювачами), коли це стосується інтересів дитини.

Вказано, що, крім загальних підстав недійсності правочину, законом передбачені спеціальні підстави недійсності правочину. Зокрема, такі випадки передбачені Цивільним кодексом щодо договору страхування та Сімейним кодексом Украӥни щодо договору про припинення права на аліменти для дитини у зв'язку з передачею права власності не нерухоме майно. Підстави недійсності правочину не можуть бути змінені або доповнені за домовленістю сторін, вони визначаються тільки законом.

Ключові слова: оспорюваний правочин, нікчемний правочин, моральні засади суспільства, борма правочину, вільне волевиявлення, обсяг ицвільної дієздатності. 
Постановка проблеми

Цивільний кодекс України від 16 січня 2003 року [1] (далі - ЦК України) та Цивільний процесуальний кодекс України від 18 березня 2004 року (у редакції Закону від 3 жовтня 2017 року) [2] прийняті Верховною Радою України для захисту прав та законних інтересів фізичних осіб, юридичних осіб та держави у сфері приватноправових відносин. Визнання правочину недійсним - це захист порушених прав та законних інтересів, що займає значну частину судової практики в Україні. Можливість захищати свої права шляхом визнання правочину недійсним $є$ судовим способом захисту цивільних прав та інтересів (п. 2 ч. 2 ст. 16 ЦК України). У ЦК України немає єдиного розуміння недійсного правочину, тому необхідне детальне вивчення насамперед підстав недійсності правочину.

\section{Аналіз останніх досліджень}

Тема недійсності правочинів досліджувалась такими науковцями, як I.M. Ткаченком, В.П. Шахметовою, Г.Ф. Шершеневичем, Я.М. Романюком, І.В. Давидовою, I.B. Рущаком, О.В. Перовою та іншими. Найбільш дискусійним залишається питання підстав недійсності правочину, які можуть бути передбачені тільки законом. При правозастосуванні цих норм спостерігається їх неоднакове тлумачення, що призводить до позбавлення права на захист порушеного цивільного права.

Мета статті - провести характеристику підстав недійсності правочину та класифікувати їх.

\section{Виклад основного матеріалу}

Загальні положення про правочини містяться у главі 16 ЦК України, до якої входять ст. 202-236. У ч. 1 ст. 215 ЦК України зазначається, що підставою недійсності правочину є недодержання в момент вчинення правочину стороною (сторонами) вимог, які встановлені ч. 1-3, 5, 6 ст. 203 цього Кодексу. Загальні вимоги, додержання яких 6 необхідним для чинності правочину, передбачені у ст. 203 ЦК України. Якщо одна чи обидві сторони, що вчиняють правочин, не дотримались однієї чи декількох вимог, вка- заних у цій статті, у момент вчинення правочину, то він визнається недійсним.

Недійсні правочини поділяються на два види: нікчемні та оспорювані. Нікчемні це ті, умови яких прямо суперечать законодавству. Нікчемні правочини не вимагають доведення їх нікчемності в суді, на відміну від оспорюваних. Проте у випадках, встановлених ЦК України, нікчемний правочин може бути визнаний дійсним за рішенням суду (за абз. 2 ч. 2 ст. 215 ЦК України).

До нікчемних правочинів законодавець відносить правочини: а) вчинені з порушенням вимоги про їх нотаріальне посвідчення; б) вчинені особою, яка не мала необхідного обсягу цивільної дієздатності для вчинення такого виду правочину; в) що порушують публічний порядок; г) вчинені всупереч внутрішній волі особи.

Як зазначає I. М. Ткаченко, нікчемний правочин не створює юридичних наслідків, крім тих, що пов'язані з його недійсністю. Так, у разі недійсності правочину кожна зі сторін зобов'язана повернути іншій стороні у натурі все, що вона одержала на виконання цього правочину, а разі неможливості такого повернення, зокрема, якщо одержане полягає в користуванні майном, виконаній роботі, наданій послузі, - відшкодувати вартість отриманого за цінами, що існують на момент відшкодування. Причому, якщо у зв'язку із вчиненням недійсного правочину контрагенту або третій особі завдані збитки або моральна шкода, вони підлягають відшкодуванню винною стороною. Встановлені законом правові наслідки недійсності нікчемного правочину не можуть змінюватися за домовленістю сторін [3, с. 374].

У цивільному законодавстві існує презумпція правомірності правочину, мається на увазі те, що вчинений правочин $є$ дійсним, якщо його умови прямо не суперечать законам України, або якщо недійсність правочину не визнана в судовому порядку. Разом з тим суб'єкти цивільних правовідносин повинні дотримуватись того, аби умови правочину не порушували права та інтереси жодного з його учасників чи не суперечили публічному порядку.

Згідно 3 ч. 1 ст. 203 ЦК України зміст правочину не може суперечити цьому Кодексу, 


\section{Цивільне, підприсмницьке, господарське та трудове право}

іншим актам цивільного законодавства, а також інтересам держави і суспільства, його моральним засадам. Зміст правочину - це його умови, які визначені стороною або погоджені сторонами. Щодо зазначення у ч. 1 ст. 203 ЦК України про непорушення інтересів держави і суспільства, ведеться мова про правочини, що порушують публічний порядок. Поняття “інтереси держави і суспільства” згадано у ЦК України з метою захистити публічні інтереси громадян України. Публічний порядок правочин може порушувати i тоді, якщо він спрямований на порушення конституційних прав людини, на пошкодження майна держави, незаконне відчуження приватної власності громадян України, власності територіальних громад тощо.

Щодо згадки в ч. 1 ст. 203 ЦК України про те, що зміст правочину не може суперечити моральним засадам суспільства, потрібно зауважити, що в ЦК України немає визначення поняття “моральні засади", а тому поняття "порушення моральних засад суспільства" може тлумачитися неоднаково. Під моральними засадами суспільства можна розуміти норми моралі, етики, не встановлені цивільно-правовими приписами. Морально-етичні норми не суперечать цивільно-правовим приписам, більше того, вони 3 часом можуть трансформуватися в цивільно-правові норми. До цивільно-правових положень, у яких втілені моральні засади суспільства, можна віднести Закон України "Про захист суспільної моралі" від 20 листопада 2003 року [4]. До моральних засад належить принцип добросовісності, який означає, що суб'єкти правовідносин повинні сумлінно виконувати свої обов'язки та мати повагу до прав своїх контрагентів. Також до моральних засад включаємо принцип справедливості як ревалентність дій осіб традиціям, культурі, менталітету суспільства. Саме слово “справедливість” включає мораль та чесність. Принцип справедливості є однією із основних засад не лише у цивільному праві, але й у інших галузях права. Від цього принципу походять і деякі інші, наприклад, принцип рівності як конституційна вимога існування суспільства в правовій державі, якою є Україна. Принцип розумності означає, що при вчиненні правочину необхідно враховувати інтереси всіх учасників цих правовідносин, у тому числі й інтереси держави.

Відповідно до ч. 2 ст. 203 ЦК України особа, яка вступає в правовідносини, повинна мати необхідний обсяг дієздатності для вчинення того чи іншого правочину. Під цивільною дієздатністю розуміємо здатність особи набувати цивільних прав та обов'язків і здійснювати їх, а також відповідати за невиконання покладених на особу обов'язків чи порушення прав інших учасників правочину.

Цивільна дієздатність фізичних осіб у більшій мірі залежить від психічної зрілості особи, а саме від можливості розуміти та усвідомлювати свої дії, їх значення, можливі наслідки та керувати цими діями.E чотири види дієздатності фізичних осіб:1) повна цивільна дієздатність виникає, коли особі виповниться 18 років, тобто 3 моменту досягнення повноліття. Хоча є випадки, коли повна цивільна дієздатність настає і до досягнення вісімнадцятирічного віку, це можливо у тому випадку, коли особа вступила в шлюб на законних підставах, також у тому випадку, коли фізична особа працює за трудовим договором, або має на меті займатися підприємницькою діяльністю. I ще одним виключенням буде життєва ситуація, коли особа 14 років стане матір'ю чи батьком до досягнення свого повноліття; 2) неповна цивільна дієздатність виникає 314 років і триває до 18 років. Маючи неповну дієздатність особа не може вчиняти будь-які правочини, але має право самостійно розпоряджатися результатами своєї інтелектуальної, наукової та творчої діяльності. Також якщо особа працює за трудовим договором, то вправі розпоряджатись своїм заробітком; 3) часткову цивільну дієздатність мають фізичні особи до 14 років (малолітні особи). Ці фізичні особи можуть вчиняти дрібні побутові правочини та мають право здійснювати особисті немайнові права на результати інтелектуальної, творчої діяльності, що охороняються законом; 4) обмежена дієздатність визнається за рішенням суду щодо фізичних осіб, що мають тяжкі психічні розлади, через які вони не можуть повністю усвідом- 
лювати свої дії та керувати ними. Суд може винести рішення про обмеження цивільної дієздатності, якщо особа має залежність від наркотичних речовин, алкоголю, азартних ігор і внаслідок цього приносить шкоду собі чи рідним, завдаючи їм скрутного становища у матеріальному та фінансовому плані.

Вимоги норми, що міститься у ч. 2 ст. 203 ЦК України є необхідними для вчинення правочинів, адже особа, яка не має повної цивільної дієздатності або має обмежену дієздатність, чи недієздатна, не може вчиняти ті ж правочини, які вчиняє особа із повною цивільною дієздатністю.

У ч. 3 ст. 203 ЦК України вказано, що необхідною вимогою дійсності правочину є особисте волевиявлення учасника, яке відповідає його внутрішній волі та бажанням. Так, за позовом заінтересованої особи суд визнає заповіт недійсним, якщо буде встановлено, що волевиявлення заповідача не було вільним і не відповідало його волі(ч. 2 ст. 1257 ЦК України). Воля особи - це бажання вступити в певні правові відносини та взяти на себе відповідні обов'язки. При вчиненні правочинів волевиявлення сторін повинно бути взаємним та спрямованим на досягнення певної правової мети. Звичайно, що бажання та ціль у правочині в кожної сторони буде різна, спрямована на досягнення особистої мети, але в той же час, ці зустрічні бажання сторін будуть слугувати досягненню однієї правової мети. Волевиявлення кожної із сторін повинно бути донесено до всіх учасників правочину одним iз способів волевиявлення. $\mathrm{E}$ декілька способів волевиявлення, серед яких - усне, письмове, волевиявлення виражене певною дією або мовчанням. Зазвичай зовнішне волевиявлення сторони виражають усно або письмово. Необхідно зазначити, що сторони цивільних правовідносин $є$ вільними у виборі того, у який правочин вступати, а в який ні, вільні у виборі сторони чи сторін, iз якими вони мають намір вчинити правочин, а також вільні у визначенні умов договору, який укладають, звичайно ж, відповідно до законодавства України.

Вільне волевиявлення означає, що жодного суб'єкта цивільних правовідносин ніхто не може змушувати вчиняти той чи інший правочин та виконувати обов'язки або набути прав, які суперечать внутрішній волі такої особи. У разі примушення особи до укладення договору він буде вважатись недійсним. Зовнішне волевиявлення може бути здійснено як самостійно, так і за допомогою представника, наприклад, щодо осіб, які не мають повної цивільної дієздатності. Проаналізуємо ухвалу Добровеличківського районного суду Кіровоградської області у справі № 387/554/18 від 22 серпня 2018 року. У цій справі розглядалось питання про визнання недійсною додаткової угоди оренди земельної ділянки. Позивач надав в оренду певну ділянку землі ТОВ “Згода" терміном на 10 років, після закінчення цього строку орендодавець, він же позивач у справі, не бажав продовжувати договір оренди, тому що мав намір сам використовувати земельну ділянку у власних цілях. Проте після закінчення строку оренди орендар не звільнив орендовану земельну ділянку, посилаючись на наявність додаткової угоди про продовження терміну оренди до цього договору. У свою чергу, орендодавець наполягає на тому, що жодної додаткової угоди він не підписував та не мав такого наміру, а тому він просив суд визнати цю додаткову угоду недійсною відповідно до ст. 203 ЦК України. Його позов було задоволено та цей правочин у формі додаткової угоди про продовження терміну договору оренди земельної ділянки визнано недійсним відповідно до цивільного законодавства, адже в цьому правочині не було згоди, внутрішнього бажання та зовнішнього волевиявлення однієї iз сторін правочину (орендодавця), а також ця угода не була погоджена та підписана сторонами [5].

На думку В. М. Пастернак, у кожному суспільстві воля сторін договору не є абсолютно вільною. Вона завжди залежить від загальних умов життя (соціальна складова) і конкретних потреб самих сторін [6, с. 39].

У ч. 4 ст. 203 ЦК України зазначено, що правочин має вчинятися у формі, встановленій законом. Форма правочину - це спосіб, яким суб'єкти цивільних правовідносин можуть виразити свою волю та зафіксувати iii, тим самим підтвердивши свій намір вчинити правочин та набути відповідних прав i 


\section{Цивільне, підприсмницьке, господарське та трудове право}

обов'язків. Згідно з ч. 1 ст. 205 ЦК України учасники правочину можуть самі обирати, в якій саме формі їм його вчиняти, але лише у тому випадку, якщо законом не передбачена конкретна форма правочину. Законодавцем прописано дві форми, у яких може бути виражена воля суб'єктів цивільних правовідносин: усна та письмова (електронна). Усна форма правочину застосовується тоді, коли правочин виконується в момент його вчинення, окрім правочинів, які повинні бути посвідчені нотаріусом.

Письмова форма правочину $є$ більш уживаною. У ст. 208 ЦК України вказані правочинів, які належить вчиняти у письмовій формі, зокрема це такі: 1) правочини, сторонами яких $є$ юридичні особи; 2) правочини між фізичними та юридичними особами, але лише у випадку, коли такий правочин не може бути вчинений в усній формі; 3) правочини між фізичними особами, сума яких перевищує в двадцять та більше разів розмір неоподатковуваного мінімуму доходів громадян; 4) інші правочини, щодо яких законом встановлена письмова форма.

Правочин вважається вчиненим у письмовій формі тоді, коли його умови викладено на матеріальному носії інформації, тобто на паперових (електронних) документах, у телеграмах чи листах, якими обмінялися сторони. Важливою умовою додержання вимоги щодо письмової форми правочину $\epsilon$ наявність підпису кожної із сторін вчинюваного правочину та печатки (за наявності). У випадку недотримання встановленої законодавством України форми вчинення правочину, він буде недійсним, якщо це прямо передбачено законом (ч. 1 ст. 218 ЦК України). Наприклад, у ч. 1 ст. 981 ЦК України передбачено, що договір страхування укладається у письмовій формі. Далі ч. 2 ст. 981 ЦК України звучить так: “У разі недодержання письмової форми договору страхування такий договір є нікчемним".

У п. 12 постанови Верховного Суду України "Про судову практику розгляду цивільних справ про визнання правочинів недійсними” № 9 від 6 листопада 2019 року [7] вказано, що порушення вимог закону щодо укладення правочину в письмовій формі $є$ підставою для визнання його недійсним лише в разі, коли це прямо передбачено законом, зокрема статтями 547, 719, 981, 1055, 1059, 1107, 1118 ЦК України тощо. Не може доводитися свідченням свідків не лише заперечення факту вчинення правочину або оспорювання окремих його частин, а й факт його вчинення, а також виконання зобов'язань, що виникли з правочину. Випадки, коли свідчення свідків допускаються як засіб доказування факту вчинення правочину, у ЦК України визначені прямо (ч. 2ст. 937, ч. 3 ст. 949 ЦК України).

Відповідно до ч. 5 ст. 203 ЦК України правочин має бути спрямований на реальне настання правових наслідків, що обумовлені ним. Тобто правочин, що не буде насправді спрямований на такі наслідки, вважатиметься недійсним. Такий результат матиме фіктивний або удаваний правочини. Удаваний правочин - це такий, де сторони вчиняють його з метою приховати інший правочин, що вже був вчинений. Наприклад, одна сторона видає довіреність на керування автомобілем замість того, щоб укласти договір купівлі-продажу, хоча мета сторін відповідала саме купівлі-продажу цього автомобіля. Тобто коли вчиняється удаваний правочин, то є наявний вже інший правочин, а удаваний вчиняється з метою приховати інші правовідносини.

Щодо фіктивних правочинів можна сказати, що це ті правочини, що вчиняються без мети набути прав та взяти на себе обов'язки, які обумовлені правочином. Прикладом може слугувати договір дарування дружиною автомобіля, коли насправді вчиняється цей правочин з метою вилучити автомобіль із спільної сумісної власності подружжя. Сторони фіктивного договору укладають його, знаючи завчасно, що він не буде виконуватися. В абз. 1 п. 24 постанови Пленуму Верховного Суду України "Про судову практику розгляду цивільних справ про визнання правочинів недійсними” вказано, що для того, щоб визнати правочин фіктивним, необхідно встановити умисел усіх сторін правочину.

Згідно 3 ч. 6 ст. 203 ЦК України, якщо батьки (усиновлювачі) вчинили правочин, який суперечить інтересам їхніх малолітніх, неповнолітніх чи непрацездатних дітей, або 
ж порушує їх права, наслідком такого правочину буде його недійсність (ч. 1 ст. 215 ЦК України). Укладений батьками (усиновлювачами) договір, який матиме наслідком позбавлення дітей майна, відчуження житла, чи зобов'язання від імені дитини порукою без згоди на це органів опіки та піклування вважатиметься недійсним (ч. 3 ст. 17 Закону України “Про охорону дитинства" від 26 квітня 2001 року [8]).

У ч. 1 ст. 12 Закону України "Про внесення змін до Закону України “Про основи соціального захисту бездомних громадян і безпритульних дітей” від 21 грудня 2010 року [9] передбачено, що держава охороняє і захищає права та інтереси дітей під час вчинення правочинів щодо нерухомого майна. Для вчинення будь-яких правочинів щодо нерухомого майна, право власності на яке або право користування яким мають діти, необхідний попередній дозвіл органів опіки та піклування. Правочини, вчинені батьками (усиновлювачами) щодо малолітніх, неповнолітніх дітей, які порушують їх права, є оспорюваними, тобто їх недійсність повинна бути доведена в судовому порядку шляхом заперечення дійсності такого правочину однієї із сторін чи іншої заінтересованої особи.

Крім охарактеризованих вище загальних підстав недійсності правочину, у законі визначені спеціальні підстави недійсності правочину. Наприклад, в абз. 2 ч. 1 ст. 998 ЦК України передбачено, що договір страхування також визнається судом недійсним, якщо: 1) його укладено після настання страхового випадку; 2) об'єктом договору страхування є майно, яке підлягає конфіскації. Згідно з ч. 6 ст. 190 Сімейного кодексу України від 10 січня 2002 року [10] договір про припинення права на аліменти для дитини у зв'язку з передачею права власності на нерухоме майно визнається судом недійсним за вимогою відчужувача нерухомого майна у разі виключення його імені як батька з актового запису про народження дитини.

\section{Висновки}

Підстави недійсності правочину визначають законом. Вони не можуть бути погоджені за домовленістю сторін. Аналіз цивіль- ного законодавства показує, що є загальні та спеціальні підстави недійсності правочину. Загальні підстави недійсності правочину визначені ч. 1 ст. 215 ЦК України. Спеціальні підстави недійсності правочину передбачені нормами закону, що регулюють окремі види правочину.

\section{Література}

1. Цивільний кодекс України: Кодекс, Закон України від 16 січня 2003 року URL: https://zakon.rada.gov.ua/laws/show/43515\#Text

2. Цивільний процесуальний кодекс України: Кодекс. Закон України від 18 березня 2004 року (в редакції Закону від3 жовтня 2017 року) URL: https://zakon.rada. gov.ua/laws/show/1618-15\#Text

3. Ткаченко I.M. Нікчемний та оспорюваний правочин: правова різниця між поняттями. Ученые записки Таврического национального университета им. В.И. Вернацького. Серия "Юридические науки”. 2008. № 2. T.21(60). С. 372-377.

4. Про захист суспільної моралі: Закон України від 20 листопада 2003 року URL: https://zakon.rada.gov.ua/laws/show/129615\#Text

5. Ухвала Добровеличківського районного суду Кіровоградської області у справі № 387/554/18 від 22 серпня 2018 року URL: https://zakononline.com.ua/court-decisions/ show/75732651

6. Пастернак В. М. Волевиявлення сторін як необхідна умова свободи договору / В. М. Пастернак // Митна справа. 2015.№ 5(2). С. 38-43.

7. Постанова Верховного Суду України "Про судову практику розгляду цивільних справ про визнання правочинів недійсними" № 9 від 6 листопада 2019 року https://zakon.rada.gov.ua/laws/show/v000970009\#Text

8. Закону України "Про охорону дитинства” від 26 квітня 2001 року URL: https://zakon.rada.gov.ua/laws/show/240214\#Text

9. Закону України "Про внесення змін до Закону України “Про основи соціального захисту бездомних громадян і безпритульних дітей” від 21 грудня 2010 року URL: 


\section{Цивільне, підприсмницьке, господарське та трудове право}

https://zakon.rada.gov.ua/laws/show/282317\#Text

10. Сімейний кодекс України: Кодекс, Закон України від 10 січня 2002 року URL: https://zakon.rada.gov.ua/laws/show/294714\#Text

\section{GROUNDS FOR INVALIDITY OF THE TRANSACTION}

The article analyzes the grounds for the invalidity of the transaction. It is indicated that the general grounds for the invalidity of the transaction are defined in Part 1 of Art. 215 of the Civil Code of Ukraine. This rule is valid, so it is necessary to apply the provisions of Art. 203 of the Civil Code of Ukraine.

The general requirements of the validity of the transaction are characterized, in case of non-compliance by which the parties to the transaction or one party, they are the grounds for invalidity of the transaction.

The article defines the concepts of "content of the transaction", "interests of the state and society", "moral principles of society". One of the grounds for the invalidity of the transaction is non-compliance with the requirement of compliance with the content of the transaction to the Civil Code of Ukraine, other laws, the interests of the state and society, the moral principles of society.

The necessary amount of legal capacity of an individual to commit a valid transaction is outlined. The types of legal capacity of a natural person are determined, it is indicated which transactions a natural person can perform in the presence of a certain type of legal capacity.

The concepts of "inner will" and "free will" are analyzed. The inconsistency of the will of the party to the transaction with his internal will is the basis for the invalidity of the transaction.

Failure to comply with the requirements of the law regarding the written form of the transaction, established by law, is the basis for the invalidity of the transaction only if it is expressly provided by law. There are several such cases in the law, this is mainly specified in relation to contracts.

One of the grounds for the invalidity of the transaction is the commission of a sham or fictitious transaction. The correct application of the rules on fictitious and fictitious transactions is explained. The general rule is that the transaction should be aimed at the actual occurrence of the legal consequences caused by it.

The last general ground for the invalidity of a transaction is the violation by parents (adoptive parents) of the rights and interests of their minors, minors or incapacitated children when committing transactions. The law requires the permission of the guardianship authority when concluding contracts by parents (adoptive parents), when it concerns the interests of the child.

It is indicated that in addition to the general grounds for the invalidity of the transaction, the law provides special grounds for the invalidity of the transaction. In particular, such cases are provided by the Civil Code on the insurance contract and the Family Code of Ukraine on the contract on termination of the right to child support in connection with the transfer of ownership of real estate. The grounds for the invalidity of the transaction may not be changed or supplemented by agreement of the parties, they are determined only by law.

Key words: disputed transaction, insignificant transaction, moral principles of society, form of transaction, free expression of will, volume of civil capacity. 